\title{
Rural Sustainability in the Face of Climate Change: Consultation and Adaptation in Australia's South West Corner
}

\begin{abstract}
The Margaret River region is within a biodiversity 'hot spot' and is an agricultural region famous for its premium wine production and wine, gastronomic and ecotourism. These activities are vulnerable to climate change, especially to reductions in rainfall and runoff. The region has experienced demographic growth as the wine and tourism industries have expanded, and as an educated and affluent population of retirees, second home owners, 'electronic cottagers' and alternative lifestylers has moved into the area. Two projects, a local study as part of a national evaluation of the adaptation of tourist areas to climate change and a more focused identification of vulnerable locations and activities were supported by local government, business and community organisations and several adaptive strategies were identified. The success of these projects can in part be attributed to the relatively high levels of both education and environmental awareness possessed by the local population as a matter of happenstance. Nevertheless, the original contention of this paper is that these initiatives also allow communities like Margaret River to take on the role of front-runners, providing demonstrations and learning opportunities on how to manage the transition to sustainability and guidance on how such methods might be adapted in other rural areas facing the challenges of climate change.
\end{abstract}

Keywords-Climate change; adaptation strategies; community consultation; rural tourism; Margaret River; regional exemplar

\section{INTRODUCTION}

Qince World War Two, the Margaret River $\checkmark$ region, in the far South West of Western

Received: 22-8-2017, Accepted: 09-9-2017; Published: 306-2018

Roy Jones, Emeritus Professor of Geography Curtin University Perth Western Australia

Email: r.jones@curtin.edu.au
Roy Jones

Australia, has experienced rapid demographic and economic growth. It is an amenity rich area (Argent et al., 2014) with a Mediterranean climate, scenic coastline, rolling topography, large limestone cave systems and impressive and unique forest flora and fauna. Furthermore, it is within three hours driving time of Perth, Western Australia's state capital, a growing city with a population of over 2 million [20]. The region can be said to have passed through all the stages the tourism area life cycle [6] from its discovery by 'pioneer' groups of tourists in the early and midtwentieth century to its current status as an internationally renowned wine, surfing and ecotourism destination.

However, in common with many rural regions of Australia with a high degree of dependence on tourism, the prospect of climate change presents a significant threat to Margaret River's economic and therefore its social sustainability [19]. In this paper, we will, firstly, provide some historical and geographical information on the Margaret River region, where an early twentieth century agricultural initiative failed but, in doing so, provided some of the bases for the region's subsequent tourism and more general success [14]. We then summarise the recent and prospective changes in Margaret River's climate, and especially its rainfall regimes, which threaten the sustainability of the local tourism industry and thereby of the local community more broadly. This will be followed by a consideration of two local community consultation exercises which demonstrated a high degree of community confidence in the ability of the region to adapt to the climatic challenges and resulted in a series of constructive initiatives to sustain the local environment and economy. In conclusion, we contend that Margaret River's ability to adapt to climate change is, at least in part, related to its 
success in attracting an educated, environmentally aware and relatively well-off population in recent decades. In view of this, we suggest that Margaret River may have the potential to become an exemplar to and offer guidance for other rural regions facing sustainability challenges as a result of climate change.

\section{ECONOMIC AND TOURISM DEVELOPMENT IN MARGARET RIVER}

Aboriginal populations have lived in Margaret River region for around fifty millennia [18] and the Devil's Lair limestone cave is a nationally and internationally significant archaeological site which has yielded some to the earliest examples of the production of symbolic objects (jewelry) by humans anywhere in the world [3]. Nevertheless, European attempts to settle and develop the area met with little initial success [6]. Although a few farms were established in the early nineteenth century, most early development centered on the extractive and hardly sustainable timber industry.

In the early twentieth century, however, the British government sought to alleviate a major unemployment problem following World War One by encouraging emigration and pioneer settlement [7]. At the same time, the Western Australian state government was encouraging agricultural development to diversify the economy at the end of a gold rush. The two governments entered into an agreement, the Group Settlement Scheme [9], to finance the passages of British migrants and to provide them with advice and initial assistance to clear the forest and develop dairy and fruit farms in the South West of the state. In the 1920s, 6,000 British settlers moved into the South West with the largest concentration being settled in the Margaret River region. The scheme was spectacularly unsuccessful. The soils were often poorly drained, the forest was difficult to clear, the migrants were unfamiliar with both farming and the local environment and the advice and support offered to them were inadequate. The blocks allocated to the settlers were hardly large enough to provide a family with an adequate living and the fall in agricultural prices during the 1930s Depression was often the final straw. Brunger and Selwood (1997) found that almost half of the settlers abandoned their blocks within five years and, after 25 years, only $12 \%$ of the original owners remained on their properties. While this initiative was clearly unsustainable, it did leave behind a patchwork of relatively small and often only partially cleared rural blocks, and a skeletal set of tracks linking them to small local service centres. At the same time, the first beginnings of tourist industry could be discerned. Early in the twentieth century a hotel was constructed between a popular beach and the first of the limestone caverns to be opened up to the public. By the nineteen thirties this had become a popular honeymoon destination.

After the Second World War, several of the abandoned farm blocks were reallocated to returned Australian soldiers who were more familiar with the local environment and who benefitted from the rising commodity prices of the post war boom. The exceptional surfing potential of the area was also discovered by newly affluent and mobile members of the postwar 'youth culture' [15]. Initially, these young people would simply drive from Perth and camp on the beaches or sleep in their cars and vans. In the 1960s and 1970s, however, both surfers and members of the countercultural (hippy) movement sought more permanent places to live in pleasant rural surroundings near the surf beaches. The run-down and often abandoned Group Settlement properties were cheap to purchase and attracted not only surfers but also those who wished to develop more self-sufficient lifestyles including growing organic produce and producing arts and craft items.

Simultaneously, agricultural research was being conducted on the soils of the limestone ridge extending north and south of the Margaret River town site [10]. This area was found to share soil and climate characteristics with the Bordeaux region and to have the potential for the production of high quality wines. Western Australia experienced a mining boom, and therefore a period of prosperity, in the 1960s and many Perth professionals invested in the development of vineyards and wineries in Margaret River, again often buying up former Group Settlement blocks for this purpose. The first vines were planted locally in 1967. Four decades later about 140 wineries were producing $20 \%$ of Australia's premium wine from around 5,500 hectares of vines.

Following on from these developments, Margaret River has developed a broad-based tourism industry focusing on wine, gastronomy and a wide range of coastal, forest and subterranean environmental attractions. The town 
of Margaret River now has a population approaching 5,000 and is the centre of a Shire containing ca. 15,000 people. This has prompted a considerable expansion in the town's commercial, and community services and the shire has therefore also become an attractive destination for both retirees seeking a 'tree change' and 'electronic cottagers' who can carry out their businesses remotely while residing in a pleasant rural environment [8].

\section{THE THREAT OF CLIMATE CHANGE}

Margaret River's success story of the previous half century is largely the result of its environmental assets. Its economy is therefore highly vulnerable to any adverse impacts on these assets that might result from climatic shifts. These shifts are currently occurring and are predicted to intensify. Hennesey et al. (2008), a study commissioned by the Sustainable Tourism Cooperative Research Centre from Australia's Commonwealth Science and Industrial Research Organisation provides a comprehensive account of the anticipated climatic change impacts as follows. Compared to the 1970-2000 mean, a 1.4 degree centigrade increase in temperature is predicted by 2050 if a high carbon emissions scenario remains in place. Changes in rainfall are more significant. Between the mid-1970s and 2008 , an $11 \%$ decrease in rainfall has taken place. Most of this decrease has been occurred in the winter peak rainfall period and this has produced a $50 \%$ decrease in runoff. By 2050 a further $20 \%$ decrease in rainfall is predicted with a larger drop off in runoff and a significant reduction in groundwater levels. A slight increase in extreme weather events (e.g. an increase of one in the number of days over 35 degrees centigrade per year and of ca. $2 \%$ in heavy rainfall intensity) by 2050 and a rise in sea level of 1.1 metre by 2100 are also predicted.

The potential impact of these changes on the Margaret River tourism industry and its economy more widely vary. Premium wine grapes are highly sensitive to temperature change and even a small shift may have a disproportional impact on the reputation and profits of local brands. Furthermore, to ensure the maintenance of a premium product, the viticulture industry requires specific levels of natural rainfall. While these can be, in part, substituted by irrigation, this will draw on already decreasing supplies of ground water and there is likely to be increased competition for ground water between viticulturalists and (often organic) horticulturalists. Furthermore, water levels have recently been falling in the underground limestone caverns reducing the visual impact of the reflections of the stalagmites and stalactites in the underground pools.

The giant eucalypt (karri) forest ecosystem is also vulnerable. An increase in temperatures, combined with a decrease in rainfall and ongoing population growth, significantly increases the risk of bushfires in an already fire prone area. More seriously, this unique ecosystem only exists in a strip a few tens of kilometres wide across adjacent to Australia's south westernmost coast. If significant climatic shifts occur, this forest system has limited potential to shift polewards in response to increasing temperatures or westwards in response to decreasing rainfall. Since the geomorphologic nature of the coastal zone is the most important contributor to the quality of the wave breaks, surfing would seem to be the form of tourism least likely to be adversely affected by climate change. But the prospect of sea level rise and increased frequency of extreme weather events have the potential to disrupt this industry also.

Nevertheless, there is a counter argument to these concerns. Margaret River will remain as one of the cooler and wetter parts of Western Australia. It is already an attractive destination for residents and tourists seeking to avoid the summer heat in the inland and northern parts of the state. This comparative advantage may remain or even increase under the prospective impacts of climate change.

\section{COMMUNITY CONSULTATION AND ADAPTATION STRATEGIES}

As a follow up to a national investigation of the impact of climate change on tourism regions [19], Australia's Cooperative Research Centre for Sustainable Tourism commissioned a further case study of the Margaret River wine region (Jones et al., 2010). In addition to literature and archival sources, this study reported on the findings of 377 questionnaires, 12 in depth interviews and a one day workshop with stakeholders. Jones et al. (2010, chapters 5-7) provides detailed information on the methodologies. The questionnaires were administered to visitors to (local government operated) tourist information centres across the 
region. The interviews conducted with three government, three tourist industry, three environmentalist and three community representatives. Ca. 50 local, regional and state community and government stakeholders attended the workshops. Interview schedules and further information is contained in Joes et al. (2010) While many respondents expressed some concern over the potentially adverse effects of climate change on their community, a more notable and general finding was that the vast majority felt that these challenges could be overcome. They acknowledged that higher levels of government (state, national and international) would need to regulate in order to slow the increase in the rate of production of greenhouse gases, to raise popular awareness of the problem and to inform and facilitate local response efforts. But they were generally confident that the local community had the skills and resources to steer the tourism industry and the region more generally through the likely climatic challenges ahead.

There was a consensus that the region's 'premium' reputation in viticultural terms could be built on and adopted more widely. The rapid success achieved by the area's current wines such as cabernet sauvignon could be built on through ongoing research into grape types suited to slightly warmer temperatures, such as Tempranillo. Many of these modern vineyards were already using best practice forms of water conservation. This information could be shared among all the area's viticulturalists and agriculturalists and similar high standards could be adopted and even mandated for building design and other local forms of water use. Such initiatives would be likely to gain the support of a progressive local council and could be showcased to tourists in their holiday accommodation and vineyard visits.

Furthermore, and again with the support of a sympathetic council, the area's environmental and planning controls needed to be at least maintained and, in some areas, increased. Suggested measures included larger coastal development setbacks, greater watercourse, wetland and bushland protection and restrictions on pesticide use. If was felt that the adoption of these initiatives would enable Margaret River to apply for and attain prestigious national and international environmental awards. Most of the stakeholder interviewees also felt that the successful pursuit of these initiatives would enable the area to market itself as a 'green', and therefore a premium, tourism and residential destination. Even if some adverse effects of climate change eventuated, the diverse nature of the area's attractions and the adaptable nature of the area's population would enable shifts in tourism emphasis, for example to "more beach and less bush', to be made with no more difficulty than a gradual change from one grape type to another.

These positive sentiments would appear to have been borne out by subsequent developments. In 2012, a local community organisation Sustain Margaret River affiliated with the global Transition Network to become Transition Margaret River and the first Transition Town in Australia. The first Transition Town group was established in Totnes, Devon by Rob Hopkins in 2006 and this has become the basis for a global network [12]. Transition Margaret River's facebook page (https://www.facebook.com/ TransitionMargaret River/ accessed 17/8/17) defines 'Transition' as "a community-led local approach to creating a more resilient society in the face of challenges we face in today's world, especially climate change and economic uncertainty."

Since its establishment, Transition Margaret River has collaborated with academic and state and local governments to identify strategies related to this aim. In 2016, it participated in a workshop co-sponsored by the Shire of Augusta Margaret River, the Curtin University Sustainability Policy Institute and the Cape to Cape Catchment Group (a locally-based state government environmental and land use management instrumentality). The workshop used participatory mapping techniques to identify specific social, cultural, environmental and economic sustainability hotspots and, from these, to devise adaptation pathways. These entailed the further identification of responsible stakeholders, objectives, actions and trials and evaluation processes of any initiatives to be undertaken.

One example of this process relates to the goal of effectively managing overall water supply, which is linked to Sustainable Development Goals 13 Climate Action and 6 Water. Relevant Stakeholders were identified as the Augusta Margaret River Shire, local wineries, the Wadandi (the local Aboriginal population), the Water Corporation, Forest Products (the local timber industry body) and the state Department of Fire and Emergency Services. Suggested actions 
included: "holistically review water cycle for Shire to understand use and recharge; pursue partnerships, e.g., with viticulture; investigate reinjection of aquifers; investigate desalination using renewable energy; understand Indigenous and biodiversity values around key water assets; manage and monitor 10 Mile Brook Dam for multiple use; citizen science at Ellensbrook (a creekside historic homestead, now publicly managed as a heritage tourist site) to evaluate changes to waterways and dams; develop Shire Water Management plan against multiple criteria including for emergency needs." While this is an aspirational goal at present, it is an interesting reflection of the level of environmental and political awareness and, potentially therefore, the level of resilience of the local community, its organisations and its council. As with the other initiatives cited in this section, we present this information in order to offer examples of appropriate community consultation, strategisation and implementation techniques, rather than as potentially transferable examples of environmental remediation techniques, since these will invariably require adaptation to local circumstances.

\section{CONCLUSION}

Demography Sustainability and the Wider Applicability of the Margaret River Experience

The unsustainability of the Group Settlement Scheme stands in stark contrast to the successful development of a diverse and prosperous community in Margaret River over the postwar period. While both the Group Settlers and the postwar immigrants to the region arrived with high hopes and a determination to meet the challenges that faced them, it is the contrasts between the two populations that are perhaps the most notable and the most relevant. The Group Settlers came from the other side of the planet. They were poor, largely urban and generally possessed low levels of education. They therefore lacked sufficient understanding of both the environment and the industry in which they wished to operate. Given the limited support provided to them, it was unsurprising that they were able to achieve sustainable livelihoods, especially when they were soon faced with adverse economic changes far beyond their control.
It seems likely that the current population of Margaret River will face adverse climatic changes that are also beyond their control. However, this population has a very different nature. Although it is diverse, containing as it does vignerons, retirees, alternative lifestylers and electronic cottagers, many, if not most, of them were familiar with the region before they settled there. The vignerons in particular had the benefit of accurate and scientific knowledge of the potential of the properties that they obtained and, in most cases, possessed the financial capital to withstand the delay between land purchase and the sale of their finished products. Many of the surfies and alternative lifestylers had a strong awareness of and commitment to environmental values. They were therefore able to see the potential of range of 'green 'business initiatives both in and beyond (eco)tourism.

Once this scenic area began to be populated by such people, this selective demographic process has become self-perpetuating in Margaret River and elsewhere. As Argent et al. $(2013,97)$ argue:

"Our analysis of the ecumene of southern Australia shows that creative workers are more likely than the general population to be attracted to rural areas offering diverse physical landscapes and gentrified socio-economic and cultural settings. Moreover, our analysis indicates that population density is also important, suggestive of the need for a particular 'critical mass' of economic and socio-cultural activity to attract this type of worker."

In these circumstances, the confidence of the subjects of our investigations in both their and their community's ability to surmount the challenges of climate change are less surprising. The population of Margaret River is both well placed and well suited to draw on the best evidence that is available to it, to utilise the networks its members possess with industry, government and academia, to engage and partner widely, to identify and work with other frontrunners and early adopters and, more generally, to accept that continual adaptation to change is the only path to sustainability.

Certainly, there are examples of other rural communities in Australia (e.g. Armidale, New South Wales [17]) and elsewhere (e.g. Totnes, the first Transition Town) that are engaging with climatic and economic change in this way. But "Australian rural communities typically have little accumulated knowledge of how to accomplish 
psychological re-orientation effectively" [17]. The wider challenge is therefore how to use the lessons from the successful initiatives in places like Margaret River and Armidale to assist other rural communities, and particularly those in less environmentally, economically and/or demographically favoured circumstances. The primary purpose of this paper has therefore been to highlight the methods and techniques used by a small and remote rural community that is, in general terms, well-educated and environmentally aware to combat some of the challenges presented to it by climate change. In doing so, we have sought to identify some of the ways in which rural communities can utilise both their own resources and the support available to them from 'outside' government, industry and academic sources to raise awareness, coordinate local support and devise strategies to combat sustainability challenges such as climate change.

\section{REFERENCES}

[1]. Argent, N., Tonts, M., Jones, R. and Holmes, J. A Creativity-led Rural Renaissance? Amenity-led Migration, the Creative Turn and the Uneven Development of Rural Australia. Applied Geography 44, 88-98 (2013).

[2]. Argent, N., Tonts, M., Jones, R. and Holmes, J. The amenity principle, internal migration and rural development in Australia Annals of the Association of American Geographers 104, 305-318 (2014).

[3]. Bednarik, R. Pleistocene stone pendant from Western Australia. Australian Archaeology 45, 32-34 (1997).

[4]. Brunger, A. and Selwood, H. J. Settlement and land alienation in Western Australia: the Shire of Denmark. Journal of Historical Geography 23, 478-495 (1997).

[5]. Butler, R. W. The concept of a tourist area cycle of evolution: implications for management. Canadian Geographer 24, 5-12 (1980).

[6]. Butler R. W. (ed.) The tourism area life cycle. Vols. 1 and 2. Channel View, Clevedon (2006).

[7]. Considine, S. Unemployment in Britain between the wars. Longman, Harlow (1980).

[8]. Curry, G.N., Koczberski, G. \& Selwood, J. Cashing out, cashing in: rural change on the south coast of Western Australia. Australian Geographer, 32, 109-124 (2001).

[9]. Gabbedy, J.P. Group Settlement. Part 1. Its origins, politics and administration. University of Western Australia Press, Nedlands (1988).

[10]. Gladstones, J. S. The climate and soils of Western Australia in relation to vine growing. Journal of the
Australian Institute of Agricultural Science 31, 275-288 (1965).

[11]. Hennessey, K., Webb, L. Korono, D \& Ricketts, J. Climate change scenarios for tourism sites; supplement for Cape Leeuwin. CSIRO, Canberra (2008).

[12]. Hopkins, R. The transition handbook: from oil dependence to local resilience. UIT, Cambridge (2008).

[13]. Jones, R., Wardell-Johnson, A., Gibberd, M., Pilgrim, A., Wardell-Johnson, G., Bizjak, S., Ward, D., Benjamin, K. \& Carlsen, J. The impact of climate change on the Margaret River wine region; developing adaptation and response strategies for the tourism industry. Cooperative Research Centre for Sustainable Tourism, Gold Coast (2010).

[14]. Jones, R., Diniz, A., Selwood, H.J., Brayshay, M. \& Lacerda, E. Rural settlement schemes in the South West of Western Australia and Roraima State, Brazil: unsustainable rural systems? Carpathian Journal of Earth and Environmental Science 10, 125-132 (2015).

[15]. McDonald-Lee, T. Three generations of surfing nomads. Your RAC Magazine, June/July, 28-32 (2016).

[16]. Sanders, D. From colonial outpost to popular tourism destination: an historical geography of the LeeuwinNaturaliste region 1829-2005. PhD thesis, Murdoch University.

[17]. Sorenson, A. Community development in an age of mounting uncertainty: Armidale, Australia in Halseth, G. (ed.) Transformation of resource towns and peripheries: political economy perspectives. Routledge, London (2017).

[18]. Turney, C. S. M., Bird, M.I., Fifield, L.K., Roberts, R.G., Smith, M., Dortch, C.E., Grun, R., Lawson, E., Ayliffe L.K., Miller, G. H., Dortch, J. \& Cresswell, R. G. Early human occupation at Devils Lair Western Australia 50,000 years ago. Quaternary Research. 55, $3-$ 13 (2001).

[19]. Turton, S. Hadwen, W. \& Wilson, R. (eds.) The impacts of climate change on Australian tourism destinations - a scoping study. Cooperative Research Centre for Sustainable Tourism, Gold Coast (2009).

[20]. Western Australian Planning Commission. Perth and Peel@ 3.5 million. Western Australian Planning Commission, Perth.

Prof. Roy JONES, Geography Discipline, Curtin University, GPO Box U1987, Perth, Western Australia 6845, Australia r.jones@curtin.edu.au, Dr. Garry BURKE, Curtin University Sustainability Policy Institute g.burke@curtin.edu.au and A/Prof. Laura STOCKER. Curtin University Sustainability Policy Institute 1.stocker@curtin.edu.au 


\title{
Sự bền vững vùng nông thôn trong sự đối mặt với biến đổi khí hậu: tư vấn và thích nghi ở miền Tây Nam Australia
}

\author{
Roy Jones \\ Emeritus Professor of Geography Curtin University Perth Western Australia \\ Email: r.jones@curtin.edu.au
}

Ngày nhận bản thảo: 22-8-2017; Ngày chấp nhận đăng: 09-9-2017; Ngày đăng: 30-6-2018

Tóm tắt-Vùng châu thổ sông Margaret nằm trong "điểm nóng" đa dạng sinh học và là một vùng nông nghiệp nổi tiếng với các sản phẩm rượu cao cấp, ẩm thực và du lịch sinh thái. Những hoạt động này ngày càng bị ảnh hưởng tiêu cực từ biến đổi khí hậu, nhất là sự giảm thiểu lượng mưa và lưu lượng dòng chảy. Vùng đất này từng trải qua một cuộc gia tăng dân số khi ngành công nghiệp rượu và du lịch được mở rộng, đồng thời những người về hưu, những người sở hữu hai căn nhà, những người thích lối sống xê dịch cũng ngày càng có xu hướng chuyển đến vùng này. Hai dự án - một nghiên cứu địa phương như là một phần trong cuộc đánh giá tầm quốc gia về khả năng thích ứng với biến đổi khí hậu của các vùng du lịch; và sự nhận diện tập trung hơn về các khu vực và hoạt động bị tổn thương - đã được chính quyền địa phương, các doanh nghiệp và tổ chức cộng đồng ủng hộ; và một vài chiến lược thích nghi được xác định. Thành công của các dự án này một phần do chất lượng giáo dục và nhận thức về mội trường tương đối cao của dân cư địa phương. Tuy nhiên, điều bài viết này muốn nói đến chính là việc, những sáng kiến này cũng cho phép các cộng đồng tương tự như ở vùng châu thổ sông Margaret đảm nhận vai trò của một người dẫn, cung cấp mẫu hình và co hội học tập cho những vùng nông thôn khác đang đối mặt với biến đổi khí hậu về cách thức quản lý quá trình chuyển dịch sang phát triển bền vững và những phương pháp có thể được áp dụng trong thực tế.

Tù̀ khóa-Biến đổi khí hậu; chiến lược thích nghi; tham vấn cộng đồng; du lịch nông thôn; sông Margaret; mẫu hình vùng 